\title{
Characteristics of South Asia High in Summer in 2010 and Its Relationship with Rainbands in China
}

\author{
Xiangning Cai, Yong Li, Xiakun Zhang*, Yuanyuan Bao \\ National Meteorological Center of China Meteorological Administration, Beijing, China \\ Email: ${ }^{\star}$ zhangxk@cma.gov.cn
}

How to cite this paper: Cai, X.N., Li, Y., Zhang, X.K. and Bao, Y.Y. (2017) Characteristics of South Asia High in Summer in 2010 and Its Relationship with Rainbands in China. Journal of Geoscience and Environment Protection, 5, 210-222.

https://doi.org/10.4236/gep.2017.57016

Received: December 21, 2016

Accepted: July 21, 2017

Published: July 24, 2017

Copyright (c) 2017 by authors and Scientific Research Publishing Inc. This work is licensed under the Creative Commons Attribution International License (CC BY 4.0).

http://creativecommons.org/licenses/by/4.0/

\begin{abstract}
The characteristics of the South Asia high (SAH) and subtropical westerly jets in the summer of 2010 and their relationship with the changes in rainband in China were analyzed. As shown by the results, the SAH in the upper troposphere extended northward relatively late in June 2010. Correspondingly, the subtropical westerly jets on the north side of the SAH jumped northward comparatively late, thus delaying the formation of a strong divergence field in the upper air over the Yangtze-Huaihe River valley. This was one of the main causes for the late onset of plum rains in the Yangtze-Huaihe River valley. In July, there was a vertical structure consisting of upper-level divergence and low-level convergence near the subtropical westerly jets on the north side of the SAH and in the air stream dispersal area on the northeast side of the eastward-extending $\mathrm{SAH}$, which was the dynamic mechanism bringing about frequent and extremely heavy rainstorms during the plum rain period in this year. The SAH in the upper troposphere affected the subtropical high in the lower stratosphere, and thereby led to changes in the main rainband location in China.
\end{abstract}

\section{Keywords}

South Asia High, Subtropical Westerly Jet, Changes in Rainband

\section{Introduction}

The SAH (the South Asia High) is an anticyclone system located in the upper troposphere and lower stratosphere over South Asia. The SAH and subtropical westerly jets are important parts of the East Asian monsoon system. The thermal SAH's movement up to the plateau, as well as westerly jets' sudden northerly jump in early summer, is the main sign of summer monsoon onset in East Asia. 
As circulation backgrounds at a planetary scale, the SAH and westerly jets are closely related to the northern hemispheric atmospheric circulation and Asian regional climate in summer. Other studies [1] [2] [3] [4] [5] have shown that the systematic northerly jump of the rainband in central and Eastern China is closely connected with the north-south oscillation of the SAH. According to the climatic state characteristics of the $\mathrm{SAH}$, the center of the SAH is located over the south part of the plateau in early summer every year, and westerly winds prevail over the plateau. At this point, the rainband vacillates between the Yangtze River Delta Region and South China, while rainstorms are triggered by the westerly trough system in the Yangtze-Huaihe River valley. Most of the rainstorms in Yangtze-Huaihe River valley are full-process torrential rains under the control of the westerly system. In the middle and late plum rain period, the center of the SAH jumps northward to the plateau, and its ridgeline vacillates between $28^{\circ} \mathrm{N}$ and $34^{\circ} \mathrm{N}$. At this point, the whole plateau is under the control of the SAH; the westerly jet jumps northward to $35^{\circ} \mathrm{N}-40^{\circ} \mathrm{N}$, and the mid-latitude weather system moves and evolves at an obviously slower speed [6]. The overwhelming majority of disastrous torrential rain events (e.g., continuous rainstorm and intensive rainstorm) have to do with the north-south vacillation of the SAH. In midsummer, the SAH ridgeline jumps northward over $34^{\circ} \mathrm{N}$, and rainy season in North China begins accordingly. But there are different weather characteristics from year to year. The following is a discussion on its relationship with the changes in the main rainband in China from a perspective of the characteristics of the SAH and subtropical westerly jets in the flood season of 2010, concurrent or later production of electronic products, and conformity of style throughout a journal paper. Margins, column widths, line spacing, and type styles are built in; examples of the type styles are provided throughout this document and are identified in italic type, within parentheses, following the example. Some components, such as multi-leveled equations, graphics, and tables are not prescribed, although the various table text styles are provided [7] [8]. The formatter will need to create these components, incorporating the applicable criteria that follow.

\section{Data}

Due to the limitation of the data source, this study only obtained the data of 2010 as the research object. The data adopted in this paper is the global daily mean data recorded in June-August 2010 by NCEP/NCAR (National Centers for Environmental Prediction/National Center for Atmospheric Research), including resolution, which equals $2.5^{\circ} \times 2.5^{\circ}$, physical quantity, such as the wind speed $(u, v)$ on 12 layers of iso-pressure surfaces $(100 \mathrm{hPa}, 150 \mathrm{hPa}, 200 \mathrm{hPa}, 250$ $\mathrm{hPa}, 300 \mathrm{hPa}, 400 \mathrm{hPa}, 500 \mathrm{hPa}, 600 \mathrm{hPa}, 700 \mathrm{hPa}, 850 \mathrm{hPa}, 925 \mathrm{hPa}$ and 1000 $\mathrm{hPa}$ ), vertical speed $(\omega)$, temperature $(T)$ and relative humidity (only for $300 \mathrm{hPa}$ and below). The precipitation data are $24 \mathrm{~h}$ rainfall recorded at 08:00 (Chinese Standard Time; hereinafter inclusive) every day by the National Meteorological Center. 


\section{The Relationship between the Precipitation in June-July 2010 and the SAH}

\subsection{A Survey of the Main Rainband in China in June-July 2010}

The main precipitation areas were the Yangtze River Delta region and south China in June 2010, during which 6 torrential rains occurred; the main rainband moved northward to the middle and lower reaches of the Yangtze River (Figure 1(b)). The Yangtze-Huaihe River valley ushered in the plum rain period on July 3 , and brought it to an end on July 24 (the National Climate Center). The plum rain period lasted 21 days; both onset and ending were 16 days later than the multi-year average (onset on June 17 and ending on July 8 ). The total precipitation

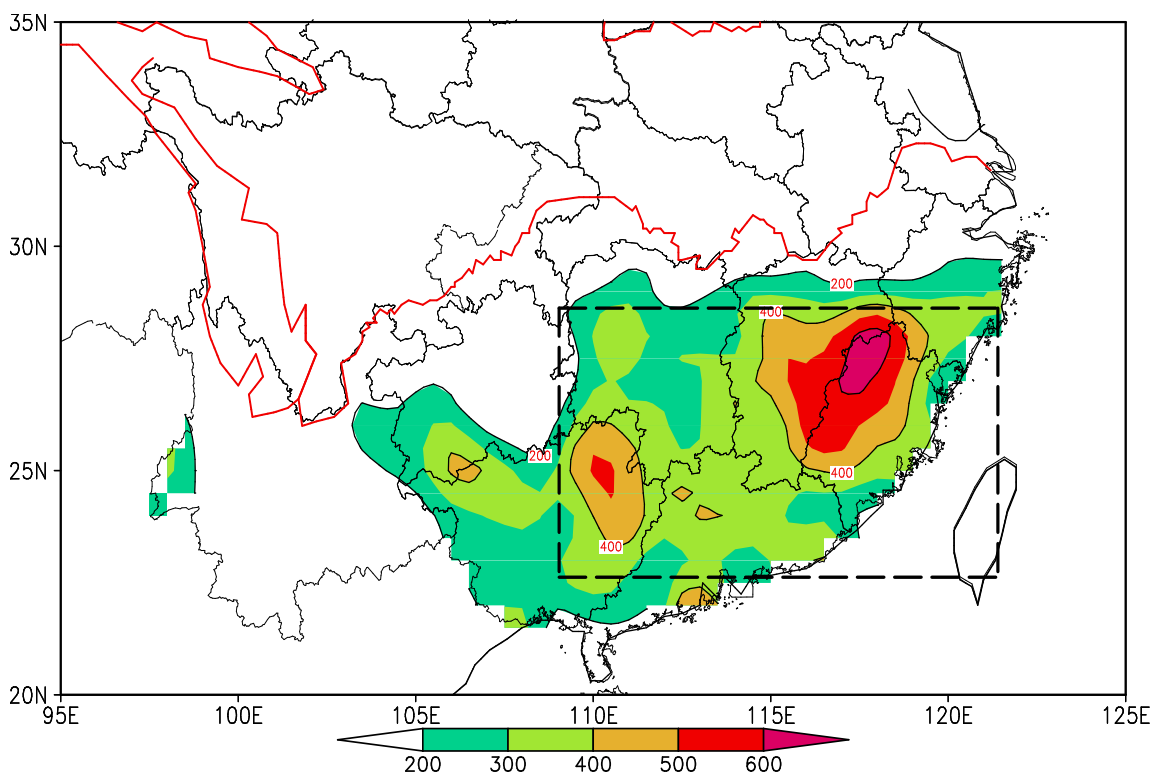

(a)

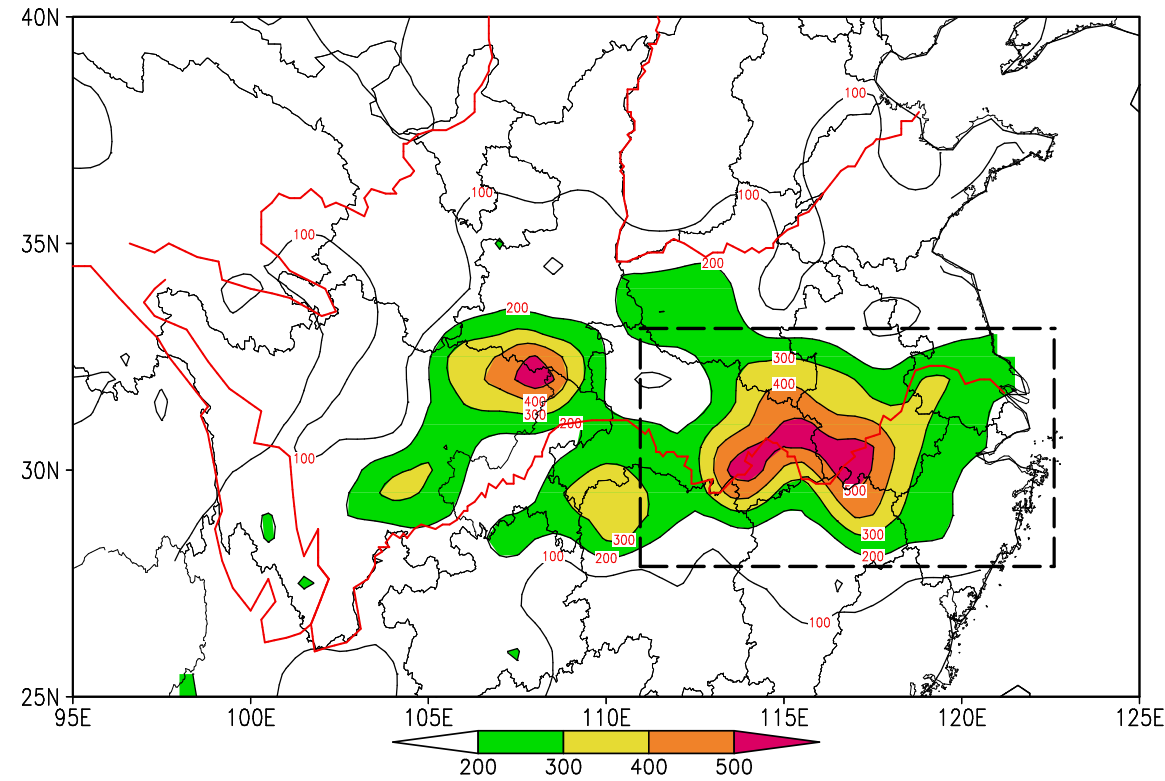

(b)

Figure 1. June (a), July (b) in 2010 cumulative precipitation. 
in Shanghai, Nanjing, Wuhu, Jiujiang and Hankou, 5 representative stations in the middle and lower reaches of the Yangtze River, reached $1522.9 \mathrm{~mm}, 26.1 \%$ higher than usual, and the index of plum rains intensity (IPRI) rose to 2.94 , relatively higher in this year.

\subsection{Characteristics of the SAH in June-July 2010}

As can be seen from the mean height field $200 \mathrm{hPa}$ in June 2010 (Figure 2(a)), the SAH presented east-west zonal distribution, the center was located near $25^{\circ} \mathrm{N} / 60^{\circ} \mathrm{E}$, and the mean $\mathrm{SAH}$ ridgeline in the eastern section at $100^{\circ} \mathrm{E}-120^{\circ} \mathrm{E}$
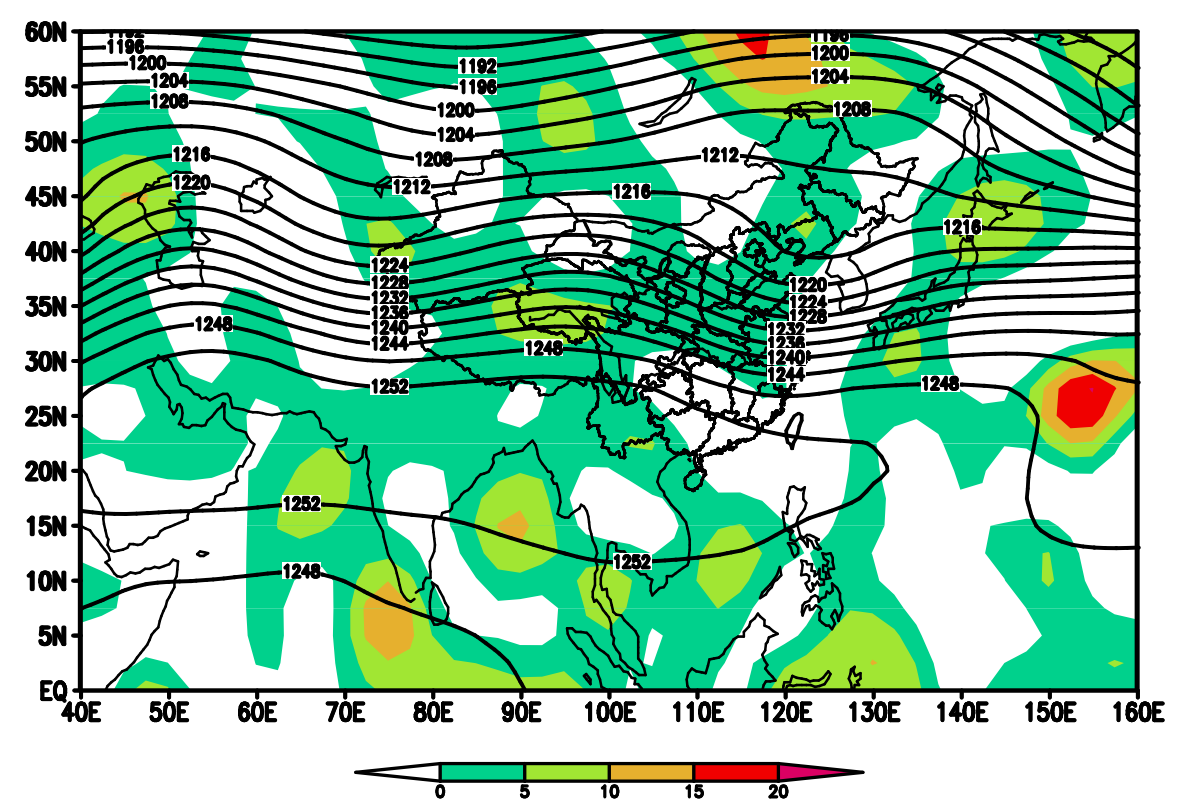

(a)

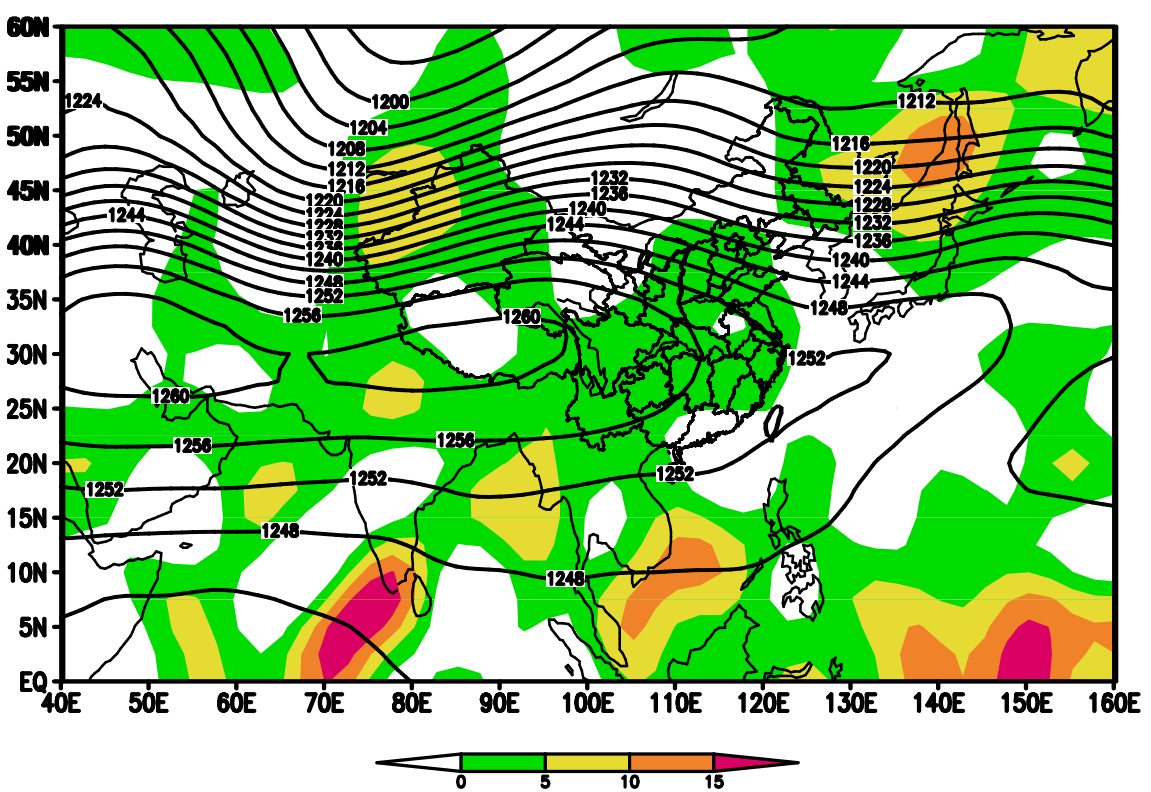

(b)

Figure 2. Average height field (dagpm) and divergence field at $200 \mathrm{hPa}$ in 2010 June (a) and July (b) (Shadow, $10^{-6} \mathrm{~s}^{-1}$ ). 
was located near $20^{\circ} \mathrm{N}$. The $\mathrm{SAH}$ ridgeline in the eastern section was more southerly than the multi-year average. According to the studies by Tao Shiyan and Zhu Fukang [1], the SAH and subtropical high over the western pacific (hereinafter referred to as the "subtropical high") move in the opposite way. So, the further south position of the ridgeline in the eastern section is unfavorable for further westerly extension of the subtropical high in the lower and middle troposphere. As a result, the intensity of the subtropical high will increase and meanwhile it will extend southward and eastward farther. This is one of the major reasons why the onset of plum rain period started later in 2010.

As can be seen from the mean height field $200 \mathrm{hPa}$ in July (Figure 2(b)), the SAH extended northward obviously compared to June, the primary center was located near $30^{\circ} \mathrm{N} / 50^{\circ} \mathrm{E}$, and there was a sub-center over the Qinghai-Tibet Plateau. The high extended eastward more obviously than June, and the 1252 dagpm isoline reached near $140^{\circ} \mathrm{E}$, roughly 25 longitudinal distances more easterly than the multi-year average. The mean $\mathrm{SAH}$ ridgeline at $100^{\circ} \mathrm{E}-120^{\circ} \mathrm{E}$ was located near $30^{\circ} \mathrm{N}$, running in NW-SE direction, known as a typical "western" or "Iran high mode". According to the studies by Luo Siwei et al. [2], the western-mode SAH corresponds to rainy weather in the middle and lower reaches of the Yangtze River, Eastern Sichuan Province, Guizhou Province and North China, yet rainless weather in Western Sichuan. As clearly shown in the time-varying map of precipitation in 2010 (Figure 3), the main rainband jumped northward obviously in July compared to June and reached $28^{\circ} \mathrm{N}-32^{\circ} \mathrm{N}$. The SAH ridgeline in the eastern section was located right above the main rainband in July. There was a slightly stronger divergence area in the north of the sub-center of the eastward-extending SAH, namely in the Huaihe River valley in China. This happened as the SAH extended eastward and the northerly air stream divergence moved southward. It interacted with the ascending motion area in the low-rise Yangtze-Huaihe River valley forming a vertical structure consisting of upperlevel divergence and low-level convergence. As a result, several torrential plum

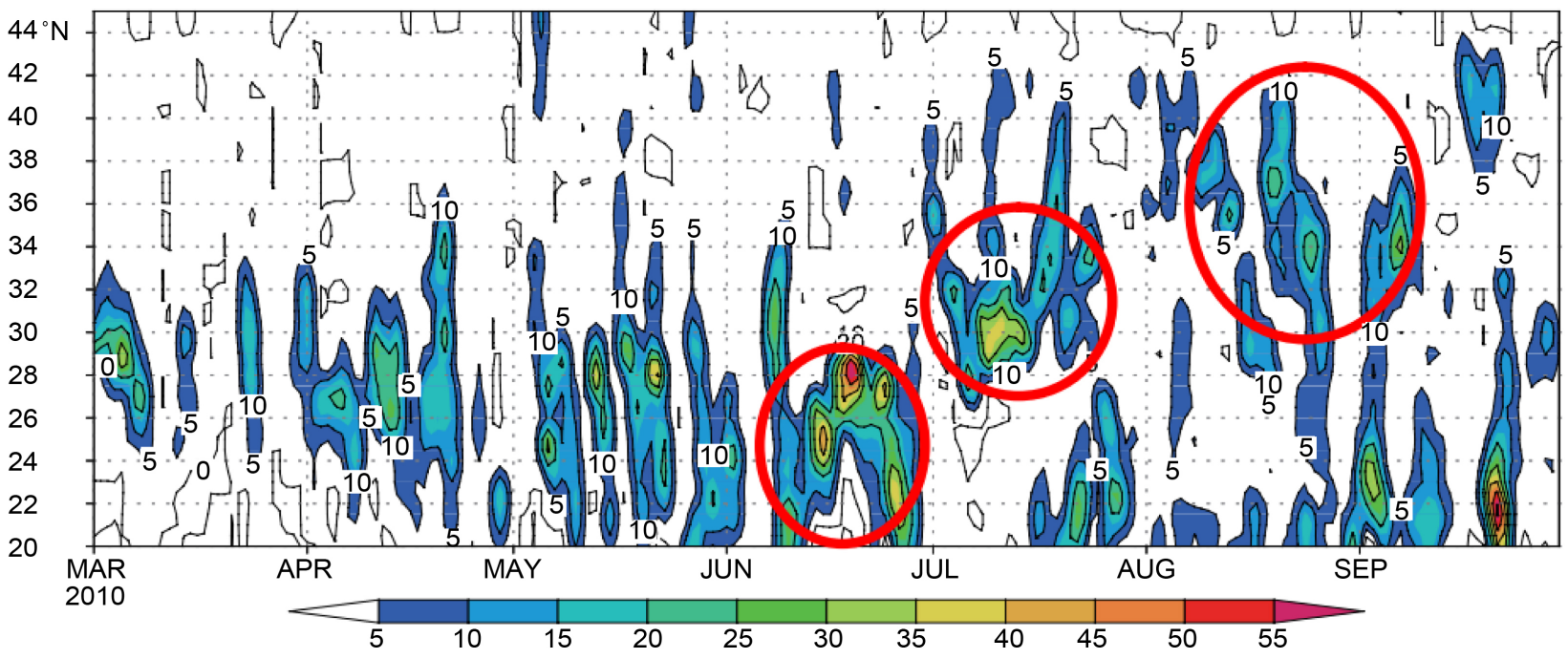

Figure 3. Time series of average precipitation from March to September 2010 from $110^{\circ} \mathrm{E}$ to $120^{\circ} \mathrm{E}$ Latitude (mm). 
rains occurred in this area in July. Convergence ascending motion was strengthened in the lower and middle troposphere in the divergence area where the northeast side of eastward-extending SAH was connected with anticyclonic circulation, contributing to the maintenance and extension of the subtropical high.

\subsection{The Relationship between the Precipitation in June-July 2010 and the SAH}

The northerly and easterly extension of the SAH is an important aerological precursor signal of plum rain onset in the Yangtze-Huaihe River valley. On June 27, the SAH began to develop rapidly, and meanwhile the mean SAH ridgeline in the eastern section (at $100^{\circ} \mathrm{E}-120^{\circ} \mathrm{E}$ ) started to extend northward fast from near $24^{\circ} \mathrm{N}$, but started to move southward gradually on July 3. It maintained steadily at $27^{\circ} \mathrm{N}-30^{\circ} \mathrm{N}$ from July 5 to 23 (Figure $4($ a)), a latitudinal zone that

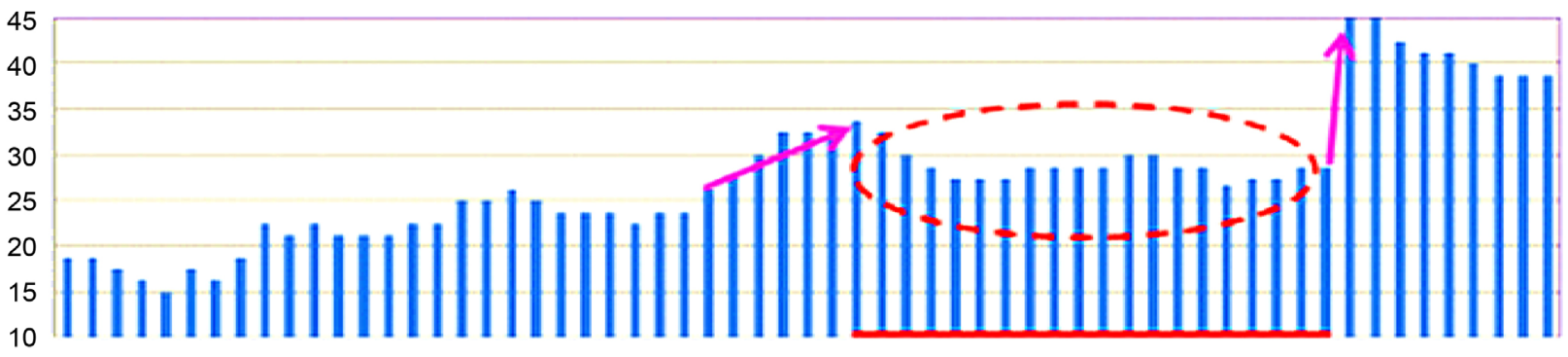

1-Jun-10 6-Jun-10 11-Jun-10 16-Jun-10 21-Jun-10 26-Jun-10 1-Jul-10 6-Jul-10 11-Jul-10 16-Jul-10 21-Jul-10 26-Jul-10 31 -Jul-10

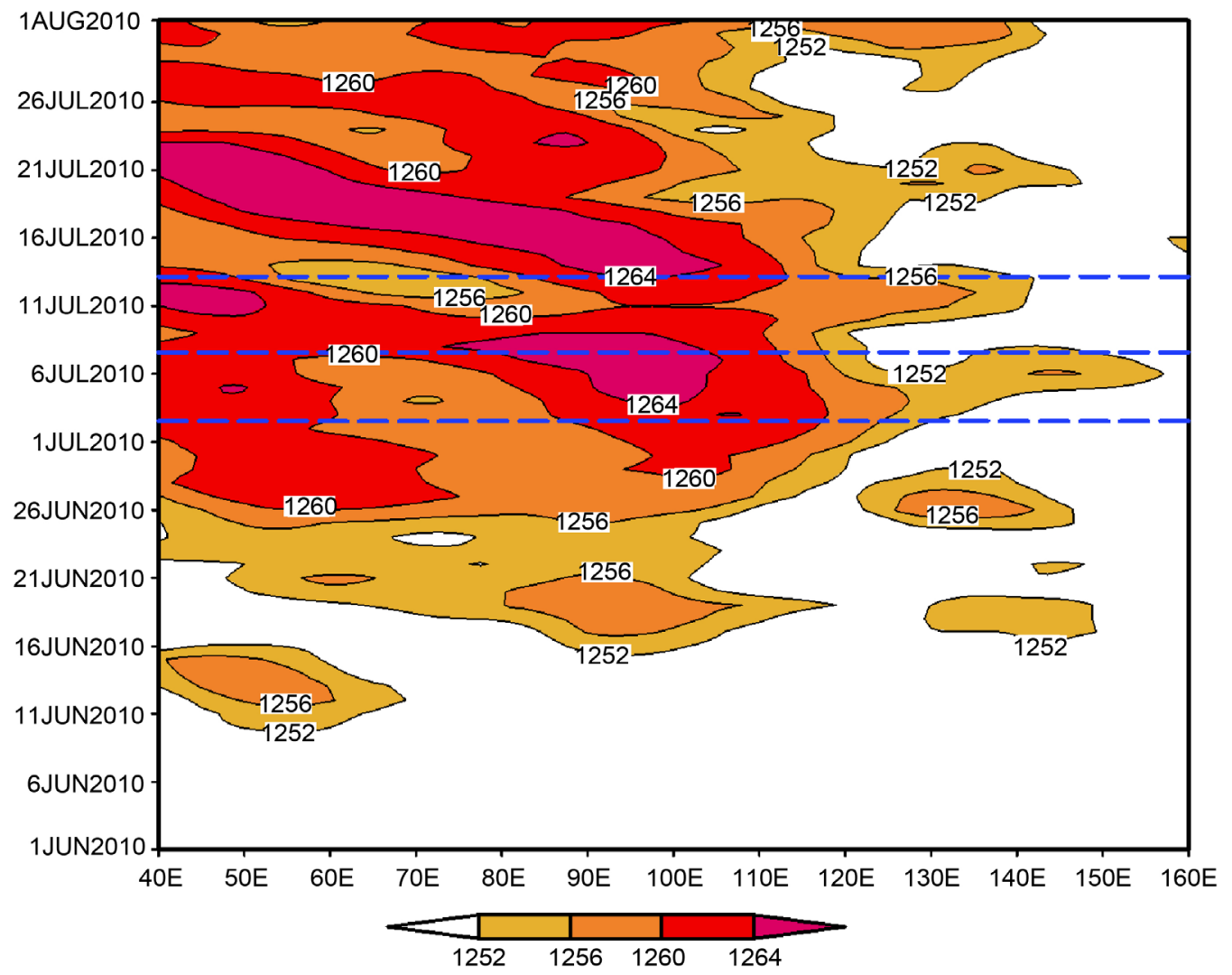

Figure 4. The eastern ridge line of the South Asian high (a) and the geopotential height of $200 \mathrm{hPa}$ (dagpm) at June-July in 2010 (b) along $30^{\circ} \mathrm{N}$ longitude-time profile (Shading indicates that the potential height is greater than 1252 dagpm). 
promoted plum rains to occur in the Yangtze-Huaihe River valley. When the ridgeline extended northward, the SAH extended eastward (Figure 4(b)). The SAH began to move eastward step by step in the middle of June, and quickened its pace suddenly after June 27 . The 1256 dagpm line strode over $120^{\circ} \mathrm{E}$ on July 3 , and the Yangtze-Huaihe River valley ushered in the plum rain period as the SAH extended eastward significantly. The circulation was adjusted again on July 23. As a result, the SAH ridgeline located in the north of the Yangtze River Delta region died out, while it began to develop dramatically over Qinghai and Western Gansu and extend eastward (Figure 4). The plum rain season came to an end gradually in the Yangtze-Huaihe River valley. As can be seen from the timevarying map of the ridgeline (Figure 4(a)), the ridgeline jumped northward suddenly to near $45^{\circ} \mathrm{N}$. Actually this was a reconstruction process of the ridgeline.

\section{The Relationship between the Precipitation in June-July 2010 and Subtropical Westerly Jets}

East Asia subtropical westerly jet is apparently seasonal [9]. Northerly jump of the high-level jet stream under $200 \mathrm{hPa}$ in June was closely related to the plum rains occurring in the Yangtze-Huaihe River valley and could be seen as an omen of plum rain onset in the Yangtze-Huaihe River valley. Especially, that the East Asian subtropical axis of jet stream extended northward and maintained steadily at further north than $38^{\circ} \mathrm{N}$ could be treated as an index signal of plum rain onset. As can be seen from the time-latitude profile of the mean zonal wind under $200 \mathrm{hPa}\left(70^{\circ} \mathrm{E}-120^{\circ} \mathrm{E}\right)$ (Figure 5), with the $\mathrm{SAH}$ extending eastward and northward, the subtropical high-level jet stream began to extend northward rapidly on June 27; the high-level jet stream core jumped by roughly 8 latitudes from $35^{\circ} \mathrm{N}$ to $43^{\circ} \mathrm{N}$ on June 3 , and accordingly, the maximum westerly wind speed increased from $35 \mathrm{~m} / \mathrm{s}$ to $53 \mathrm{~m} / \mathrm{s}$ (Figure 5). The high-level jet stream disappeared around July 23 and re-emerged to the north of $45^{\circ} \mathrm{N}$. As a result, the plum rain period began in the Yangtze-Huaihe River valley.

According to the mean flow field under $200 \mathrm{hPa}$ from July 3 to 23, 2010 (Figure 6(a)), the center of the SAH was located over Eastern Tibet at $95^{\circ} \mathrm{E}$, while the average ridgeline was located near $28^{\circ} \mathrm{N}$. The high-level jet stream core was located over Southern Xinjiang and formed a wide air stream divergence area between the high-level jet stream and SAH ridgeline. The Yangtze-Huaihe River valley was gripped by an upper-level strong divergence field (Figure 6), and the upper-level divergence effectively promoted the formation of rains in the Yangtze-Huaihe River valley. Besides, according to the anomaly field (Figure 6(b)), there were two anticyclonic circulations over Qinghai and Eastern Japan. The anticyclonic circulation over Qinghai enhanced the high-level jet stream, and thereby stabilized the up-level divergence field.

The analysis above shows that the SAH in the upper troposphere extended northward relatively late, and accordingly, the subtropical westerly jet on the north side of the SAH jumped northward comparatively late, thus delaying the 


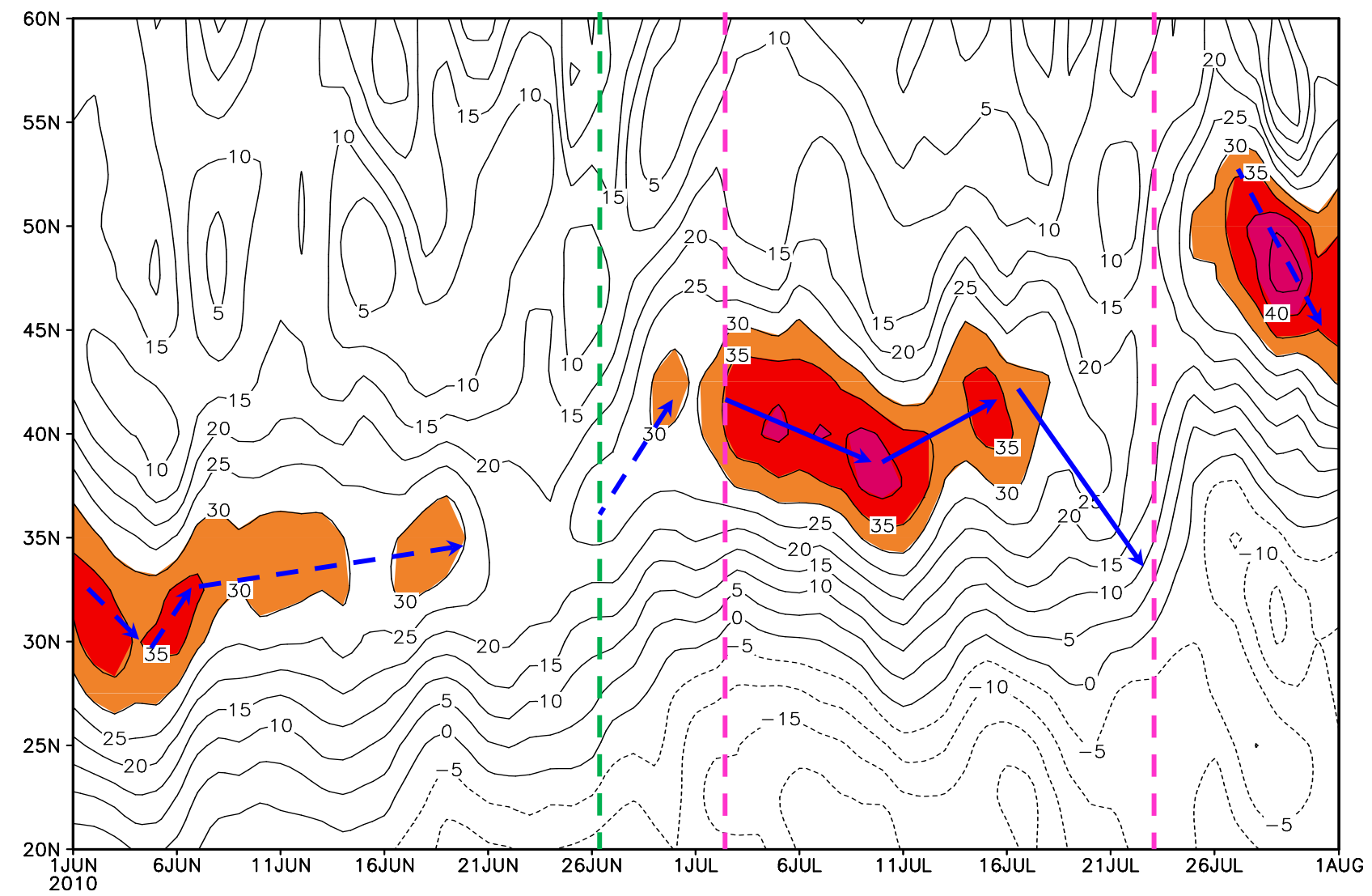

Figure 5. Latitude-time profile of $200 \mathrm{hPa}$ mean zonal wind $\left(70^{\circ} \mathrm{E}-120^{\circ} \mathrm{E}\right)$ at June-July in $2010(\mathrm{~m} / \mathrm{s})$ (Shading means wind speed $\geq$ $30 \mathrm{~m} / \mathrm{s})$.

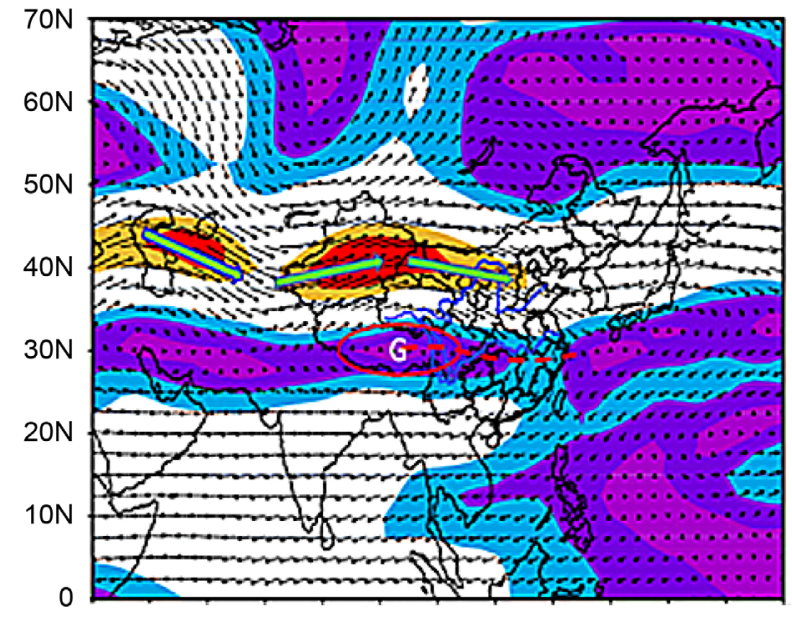

40E 50E 60E 70E 80E 90E 100E 110E 120E 130E 140E 150E 160E

(a)

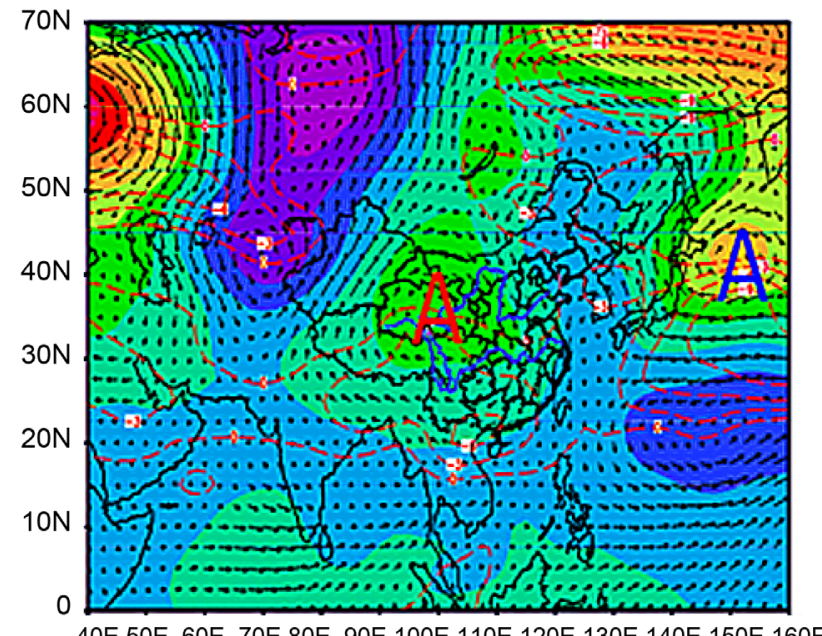

40E 50E 60E 70E 80E 90E 100E 110E 120E 130E 140E 150E 160E

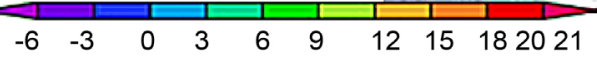

(b)

Figure 6. The mean flow field (a) and the anomaly field (b) under $200 \mathrm{hPa}$ from July 3 to 23, 2010 (unit: $\mathrm{m} / \mathrm{s}$ ).

formation of a strong divergence field in the upper air over the Yangtze-Huaihe River basin. This was one of the main causes for the late onset of plum rains in the Yangtze-Huaihe River valley in 2010. The SAH in the upper troposphere en- 
tered Iran mode after the onset of plum rains in 2010, the center of the high moved further westward and the intensity increased. There was a vertical structure consisting of upper-level divergence and low-level convergence near the subtropical westerly jet on the north side of the SAH and in the air stream dispersal area on the northeast side of the eastward-extending SAH, which was the dynamic mechanism bringing about frequent extremely heavy rainstorms during the plum rain period in this year.

\section{The Relationship between the Precipitation and SAH in August 2010 and Subtropical Westerly Jets}

In August, the SAH extended eastward obviously compared to July. As shown by the mean height field under $200 \mathrm{hPa}$ in August (Figure 7(a)), the primary center of the SAH was located near $31^{\circ} \mathrm{N} / 80^{\circ} \mathrm{E}$, while the mean $\mathrm{SAH}$ ridgeline in the eastern section was located near $32^{\circ} \mathrm{N}$. As clearly shown in the time-varying map of precipitation in 2010 (Figure 3), the main rainband jumped northward obviously compared to July and reached the southern part of Northern China, as well as the Huang-Huai River valley. In the north-northeast of the SAH where it began to move southward and in front of the westerly trough there was a strong divergence center, which exactly corresponded to the ascending motion area on the northwest side of the subtropical high in the middle and lower troposphere, and the rainband from North China to the Huang-Huai River valley was right below it. Since there was a strong subtropical frontal zone between the strong westerly trough in the upper troposphere over North China and the strong SAH, the subtropical westerly jets were strong as well (Figure $7(b)$ ). The jet stream core was located over the eastern part of Northwest China, which formed a wide air stream divergence area between the high-level jet stream and the SAH ridgeline. The southern part of North China, as well as the Huang-Huai River valley, was gripped by the high-level strong divergence field, and saw ample rainfall.

\section{The Mechanism of the Dynamic Influence of the SAH on the Subtropical High}

According to the studies by Tao Shiyan and Zhu Fukang (1964), the SAH and subtropical high move in the opposite way. The following is a brief analysis on the mechanism of the SAH's dynamic influence on the subtropical high based on the derivation of vorticity by Wu Guoxiong and Liu Huanzhu [10].

Figure 8 illustrates the longitude-time profile of the negative vorticity advection along $4^{\circ} \mathrm{N}$ under $200 \mathrm{hPa}$ in July-August 2010. As clearly shown in the Figure 8, the SAH kept extending eastward after July 3, accompanied by the easterly movement of negative vorticity advection (interrupted for several times). It moved eastward beyond $125^{\circ} \mathrm{E}$ and even farther. During this period, for a certain longitude, the local change of vorticity is a minor term, which can be ignored, so,

$$
\vec{V} \cdot \nabla \zeta+\beta v=f \frac{\partial w}{\partial z}
$$



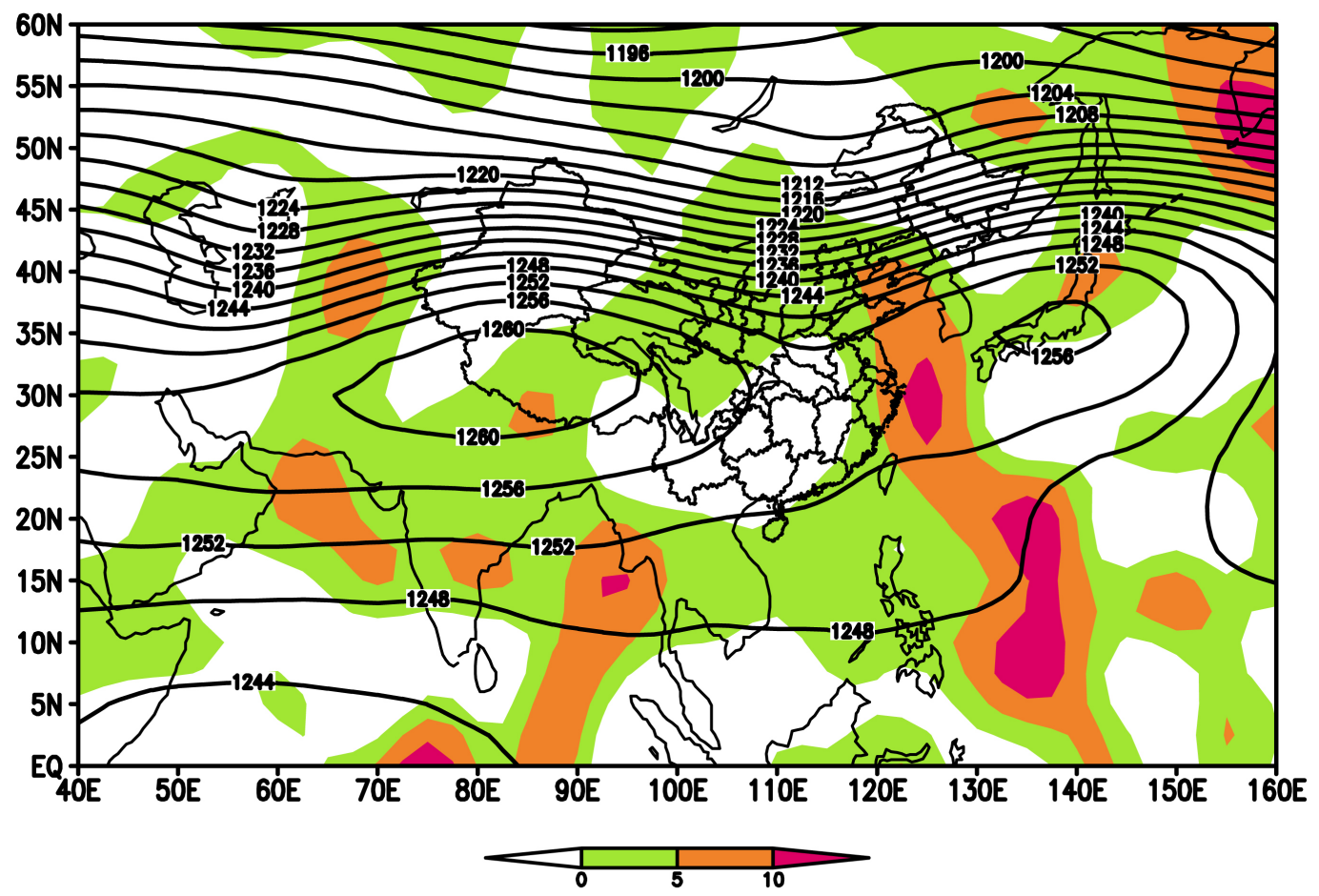

(a)

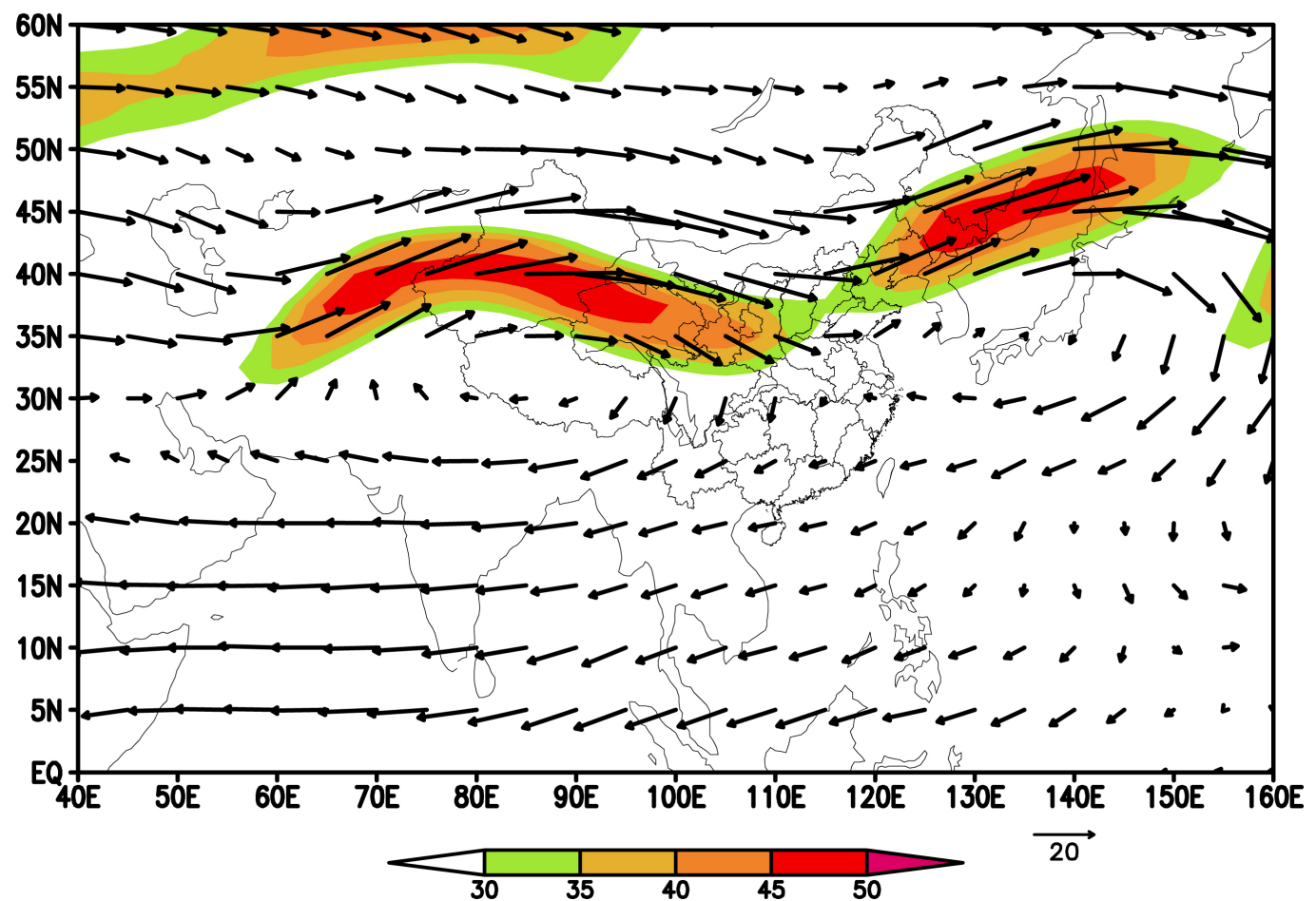

(b)

Figure 7. $200 \mathrm{hPa}$ average height field (a), unit: dagpm, the shadow of the divergence field, unit: $10^{-6} \mathrm{~s}^{-1}$ ) and the flow field at August in 2010 (b), the shadow of the wind speed $\geq 30 \mathrm{~m} / \mathrm{s}$ ).

$\mathrm{Z}$ was differentiated on either side of this equation, reducing to:

$$
\frac{\partial}{\partial z} \vec{V} \cdot \nabla \zeta+\beta \frac{\partial v}{\partial z}=f \frac{\partial^{2} w}{\partial z^{2}} \propto-f w
$$


So,

$$
w \propto \frac{1}{f} \frac{\partial}{\partial z}(-\vec{V} \cdot \nabla \zeta)-\frac{\beta}{f} \frac{\partial v}{\partial z},
$$

If there is a strong negative vorticity advection $-\vec{V} \cdot \nabla \zeta<0$ under $200 \mathrm{hPa}$ in the $\mathrm{SAH}$, and the negative vorticity advection slows down in the middle and lower levels, $w<0$ by Equation (3), and there should be descending motion developing below it to promote the development of divergence and negative vorticity in the middle and lower levels. With the SAH extending eastward, the strong negative vorticity advection near its ridgeline can drive the development of the anticyclonic circulation in the lower level, to intensify the subtropical high.

On the days that saw the interruption of negative vorticity advection, since the westerly trough located over Xinjiang moved eastward farther, some positive vorticity advection moved eastward along the north side of the SAH, depriving the middle and lower troposphere of the condition that was good for the development of anticyclonic circulation. After the negative vorticity advection was interrupted for one or two days, the subtropical high retreated eastward, during which line 588 withdrew from Mainland China (Figure 8). By this token, the movement of high-level vorticity advection has something to do with the longitudinal oscillation of the subtropical high in the middle and lower levels.

But due to the easterly extension of the $\mathrm{SAH}$, the anticyclonic circulation in the divergence area on the northeast side of the SAH brought the north wind on by $-\beta_{V}>0$, since the north wind was strengthened with height. According to the second term of Equation (3), lower-level convergence ascending motion might achieve development here, and the ascending motion led to latent heat release in the upper troposphere, increasing the non-adiabatic heating rate of the upper level, concluding that the subtropical high moved westward farther.

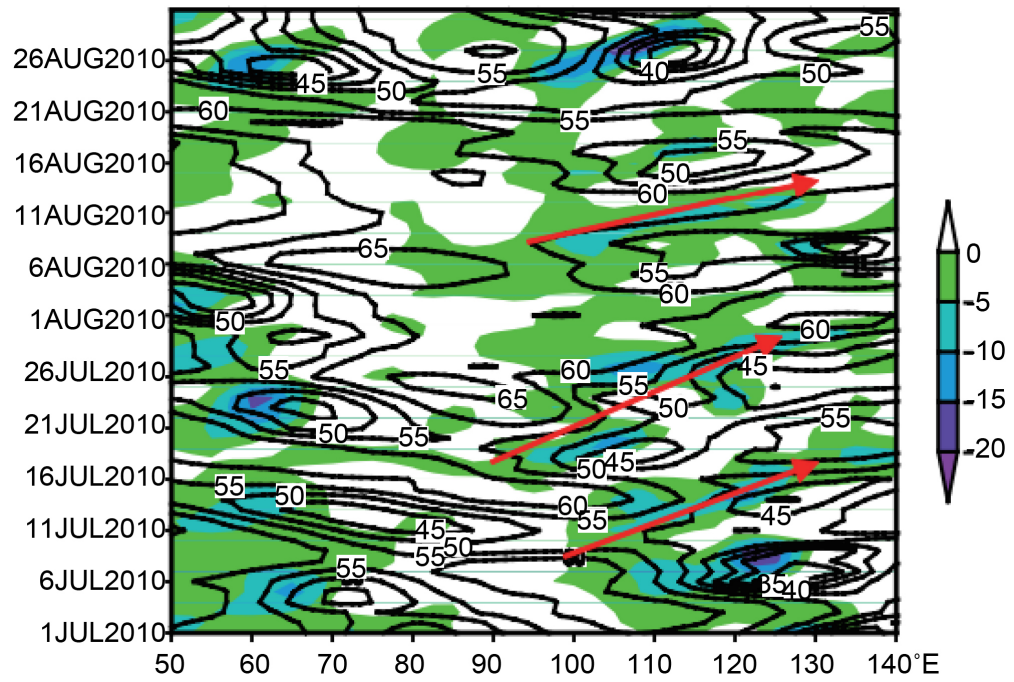

Figure 8. At July-August in 2010 Longitudinal-time profiles of height and negative vorticity advection at $34^{\circ} \mathrm{N} 200 \mathrm{hPa}$ (Contour is height, dagpm, minus 1200 dagpm; negative vorticity advection in the shadow area, unit: $10^{-10} \mathrm{~s}^{-2}$ ). 
The above analysis shows that the negative vorticity advection spreading eastward to the north of the $\mathrm{SAH}$ ridgeline under $200 \mathrm{hPa}$ kept moving eastward with the SAH extending eastward, and convergence descending motion sped up in the middle and lower troposphere within the subtropical high, while convergence became obvious in the upper troposphere, showing typical dynamic high pressure features, promoting the subtropical high in the middle and lower troposphere to extend westward farther. Meanwhile, on the northeast side of the eastward-extending $\mathrm{SAH}$, divergent anticyclonic circulation and northerly wind developed, strengthening convergence ascending motion in the middle and lower levels, enhancing precipitation. So as can be seen, the upper-high SAH affects the middle and lower level systems and thereby leads to changes in the main rainband in China.

\section{Conclusions}

According to the study, the South Asia high advance and retreat activities have a very close relationship with the eastern part of China's drought and floods.

1) The eastern SAH ridgeline moved to a further south position in June 2010, and correspondingly, the subtropical westerly jet on the north side of the SAH jumped northward comparatively late, thus delaying the formation of a strong divergence field in the upper air over the Yangtze-Huaihe River basin. This was one of the main causes for the late onset of plum rains in the Yangtze-Huaihe River valley in 2010.

2) The SAH extended eastward and northward in July 2010, with which the subtropical westerly jets extended northward. It interacted with the ascending motion area in the low-rise Yangtze-Huaihe River valley forming a vertical structure consisting of upper-level divergence and low-level convergence. This was the dynamic mechanism bringing about frequent extremely heavy rainstorms during the plum rain period this year.

3) The SAH in the upper troposphere affected the subtropical high in the lower troposphere, and thereby led to changes in the main rainband location in China.

In normal years, the movement of the rainband is slow northward and southward. China's southern rainy season began early, late evening, rainy season long, precipitation and more uniform. The northern rainy season begins late, ends early, the rainy season is short, and the precipitation is small and concentrated.

China's eastern region of the major rivers from south to north has been flooding, and the flood season is generally more to the north short. China's middle and lower reaches of the Yangtze River region stay rainy, mid-June to mid-July, due to rainband wandering. In the summer and autumn of August, the area was affected by the subtropical high ridge, and the subsurface airflow prevailed to form a dry weather.

In the past year, the summer monsoon in eastern China is strong; the rain belt has entered the north fast, and the north will flood; if the summer wind in the weak year, the rainband northward slow, then there will be flooding The There- 
fore, by analyzing the characteristics of the South Asian high pressure and subtropical westerly currents in the summer of 2010 and its relationship with the change of the rainband in China, it is predicted that the change of the main rainband position in China will strengthen the weather monitoring and forecasting in the agricultural production and do a good job in disaster prevention and construction of disaster prevention measures.

\section{Funding}

This work was funded by the National Science and Technology Support Program (2015BAC03B04, 2015BAC03B06, 2015BAC03B07) of China.

\section{References}

[1] Tao, S.Y. and Zhu, F.K. (1964) The 100-MB Flow Patterns in Southern Asia in Summer and Its Relation to the Advance and Retreat of the West-Pacific Subtropical Anticyclone over the Far East. Acta Meteorological Sinica, 34, 385-399.

[2] Luo, S.W., Qian, Z.A. and Wanf, Q.Q. (1982) The Climatic and Synoptical Study about the Relation between the Qinghai-Xizang High Pressure on the 100MB Surface and the Flood and Drought in East China in Summer. Plateau Meteorology, 1, $1-10$.

[3] Liu, H.Z., Zhao, S.R., Zhao, C.G., et al. (2006) Weather Abnormal and Evolution of Western Pacific Subtropical High and SOUTH ASIAN Hing in Summer of 2003. Plateau Meteorology, 25, 169-178.

[4] Hu, J.G., Tao, L. and Zhou, B. (2010) Characteristic of South Asia High Activity and Its Relation with the Precipitation of East China in Summer. Plateau Meteorology, 29, 128-136.

[5] Huang, Y.Y. and Qian, Y.F. (2004) Relation between South Asian High and Characteristic of Precipitation in Mid- and Lower-Reaches of Yangtze River and North China. Plateau Meteorology, 23, 68-74.

[6] Qian, W. (2017) Weather and Climate//Temporal Climatology and Anomalous Weather Analysis. Springer, Singapore, 1-30.

[7] Hady, D.H.A. and Shalaby, M. (2016) Transmuted Laplace Distribution: Properties and Applications. American Journal of Applied Mathematics and Statistics, 94-98.

[8] Ganeshprabu, B. and Geethanjali, M. (2016) Dynamic Monitoring and Optimization of Fault Diagnosis of Photo Voltaic Solar Power System Using ANN and Memetic Algorithm. Circuits and Systems, 7, 3531.

https://doi.org/10.4236/cs.2016.711300

[9] Kuang, X.Y. and Zhang, Y.C. (2006) Impact of the Position Abnormalities of East Asian Subtropical Westerly Jet on Summer Precipitation in Middle-Lower Reaches of Yangtze River. Plateau Meteorology, 25, 382-389.

[10] Wu, G.X. and Liu, H.Z. (1999) Complete Form of Vertical Voricity Tendency Equation and Slantw ISE Voricity Development. Acta Meteorologica, 57, 1-15. 
Submit or recommend next manuscript to SCIRP and we will provide best service for you:

Accepting pre-submission inquiries through Email, Facebook, LinkedIn, Twitter, etc. A wide selection of journals (inclusive of 9 subjects, more than 200 journals)

Providing 24-hour high-quality service

User-friendly online submission system

Fair and swift peer-review system

Efficient typesetting and proofreading procedure

Display of the result of downloads and visits, as well as the number of cited articles Maximum dissemination of your research work

Submit your manuscript at: http://papersubmission.scirp.org/

Or contact gep@scirp.org 